\title{
腐植土生成に関する実験的研究 ${ }^{1)}$
}

\author{
熊田恭 -22)太田誠 - 2) \\ Experimental Sudies on the Formation of Humic Soil
}

Kyoichi Kumada and Seiichi Ohta

\begin{abstract}
As a model experiment aiming at the role of allophane and aluminium for elucidating the formative mechanisms of humic soil, the browning reactions of pyrogallol, catechol and hydroquinone were examined spectrophotometrically in the presence of three soils (G-horizons); Tenmondai (volcanic ash soil, allophane), Zenjino (strongly acid red-yellow soil, monmorillonite) and Higashiyama (acid red-yellow soil, kaolin minerals).

The formation of complexes between aluminium and purpurogallin or an unknown compound derived from catechol, and between iron and catechol was distinctly recognized in the presence of Tenmondai and Zenjino.

It was deduced that the formation of these complexes and browning substances influenced by soil materials and their adsorption on soils increased in the order of Tenmondai, Zenjino and Higashiyama.

Hydroquinone may be the best model compound among the three polyphenols.
\end{abstract}

\section{1. 緒}

腐植化作用は土壤中における有機物の褐変であるとす る考えは古くから提出されていた（能田：1961）．この ことは，たとえば SGHEFFER（1960）がその著書の中で 腐植生成の化学の項で述べている内容は, 褐变現象一般 の総括であることからも明らかである.

褐变現象は，酵素的および非酵素的に生起する暗色無 定形の高分子物質の生成反応であり，多種類の有機物が その出発材料となるが，ポリフェノール類はとくに容易 に褐変する物質群である。なお，Dubach and Mehta (1963) は，腐植物質は aromatic-phenolic polymer で あるとしている.

さて, 火山灰土A層, 黒ボク, 火山性土中の腐植質埋 没土層などの腐植土は, 噟植化度の高い腐植酸すなわち Kumada et al (1967) の分類に打けるA 型腐植酸を多 量に含有する. この型の腐植酸の生成と集積には, アロ フェンあるいはある種のアルミナが有機物を褐变させ, さらに生成した褐变物質を吸着保持する能力をもつこと が1つの必須条件であるうと推測されるが，この点に関 する実験例はきわめて少ない.

ポりフェノールの褐変すなわち酸化重合に対するア ロフェンの効果については, Kyuma and Kawaguchi
（1964）の研究があるが，著者らも上述の推論を実証す るために, ポリフェノールの褐変と各種の土壤物質との 関係に関する一連の実験を進めてきた。本報では前報 (Kumada and Kato: 1970) につづき，腐植土生成に関 するモデル実験として，3 種のポりフェノールと 3 種の 土壤物質を用いて, 褐変状況, 褐变物質の集積などにつ いて調べた結果の概要を報告する。

\section{2. 試料}

a. ポリフェノール

ピロガロール，カテコールおよび，ヒドロキノン．い ずれも特級または 1 級試薬を用いた。

\section{b. 土猿物贾}

天文台：東京都三鷹市天交台構内. 関東 (立川)口一ム， 腐植質火山灰土 C 層 $(75-225 \mathrm{~cm})$.

善師野：愛知県犬山市善師野，第三紀頁岩に由来する 赤黄色土 G 層 $(40-80 \mathrm{~cm})$.

東山: 名古屋市千種区不老町 名古屋大学構内, 洪積 世八事層の赤黄色士 $\mathrm{C}$ 層 $(15-50 \mathrm{~cm})$.

これらの土壤の細土または細微土を過酸化水素処理に よって有機物を分解した後使用した.

1) 1971.8 .19 受付

2) 名古屋大学農学部 Faculty of Agriculture, Nagoya University 


\section{3. 実 験 方 法}

[実験 I] ポリフェノール溶液の褐変と土㖡物質

ピロガロール $50 \mathrm{mg}$ ，カテコールまたはヒドロキノ ン $220 \mathrm{mg}$ と上記の細微土 (ピロガロールの場合 $50 \mathrm{mg}$ その他では $220 \mathrm{mg}$ ）を $50 \mathrm{ml}$ 容ビーカーに秤取し，酢 酸塩緩衝液（酢酸で $p \mathrm{H}$ を 6.0 に調整した $0.1 \mathrm{~N}$ 酢酸 ナトリウム溶液） $20 \mathrm{~m} l$ を加え， アルミフォイルで覆 い, $30^{\circ} \mathrm{C}$ の定温器に入れ， 24 時間および 48 時間後に 遠心分離して，透明な上澄液をえた。この溶液の吸光度 を波長 $700 \sim 230 \mathrm{~m} \mu$ 付近にわたり日立 124 型分光光度 計で測定し，吸光度 (対数目盛)-波長困として吸光曲線 を図示した，濃度は特記するものの他はすべて上記の濃 度である。

なお，土壤物質無添加の 対照についても同時に 測定 し，また定温器中に放置するさい，棌濁液を時々攪拌し た場合と静置した場合の比較も行なった。

[実験 II] 土壤物質中におけるポリフェノールの褐変

風乾細土 $25 \mathrm{~g}$ にポリフェノール $2.5 \mathrm{~g}$ を混和して $50 \mathrm{ml}$ 容ビーカーに入れ，最大容水量の $60 \%$ に相当す る水を加え, アルミフォイルで覆い, $30^{\circ} \mathrm{C}$ の定温器に 静置した. 20 日後にとりだし，50C で乾燥し，乳鉢で 粉砕した後, ソックスレー装置によりエタノール可溶性 物質を抽出した.

抽出液はエタノールを加えて $100 \mathrm{~m} l$ とし，その吸光 曲線を測定した。

エタノール抽出残渣は乳鉢で 粉砕して $0.5 \mathrm{~mm}$ の篩 をすべて 通過させた後, 腐植の形態分析法 (Kumada et al，1967) に準じて分析した.

すなわち，東山・ヒドロキノン試料では $3 \mathrm{~g}$ ，善師野。 ヒドロキノンでは $1 \mathrm{~g}$ ，その他の試料はすべて $0.5 \mathrm{~g}$ を 用い, $0.1 N$ 水酸化ナトリウム可溶性有機物を加熱抽出 乙 $\left(100^{\circ} \mathrm{G}, 30\right.$ 分)，遠心分離してえた上澄液を“腐植 酸部”と“フルボ酸部”に分別し，後者はふたたびアル カリ性とし，両部分について吸光曲線と過マンガン酸カ リウム消費量を測定した. また 試料について直接過マ ンガン酸カリウム消費量を測定し，この值をもって試 料の 全有機物量を表わすこととした。結果の表示法は Kumada et al (1967) によった.

さらに, 適量の試料に $0.1 M$ ピロリン酸ナトリウム溶 液（ピロリン酸で $p \mathrm{H}$ を 6.0 に調整） $20 \mathrm{ml}$ を加え， 24 時間時々振浔しながら $30^{\circ}$ に放置してえられた抽出 液についても，吸光曲線を測定した。

\section{3. 実験結果と考察}

実験 1 の測定結果の数例を第 1〜4 図に示した. 先述のポリフェノール溶液は溶解直後無色であるが, 時間の経過とともに次第に着色する.この呈色の様相お よびこれに及ぼす各種の粘土やアルミニウム $(\mathrm{Al})$ と鉄 イオンの影響などについては，ピロガロールの場合につ いて一部報告したが (Kumada and Kato, 1970) その 他については別に報告する予定である。ここでは本実験 の結果の解釈に必要な点のみを摘記する.

1.ピロガロール単独の場合，はじめ無色の溶液は時 間がたつにつれて，黄色から赤褐色をへて黒褐色とな る. 吸光曲線は初め $266 \mathrm{~m} \mu$ に 1 個の 吸収極大（ピー ク）をもつのみであるが，やがて $300,360,435 \mathrm{~m} \mu$ に ピークまたは肩状の吸収带が現われ，時間の経過ととも に光吸収はほぼ全波長域にわたって増大する.なお 266 $\mathrm{m} \mu$ 以外の吸収帯はプルプロガリンの生成による.

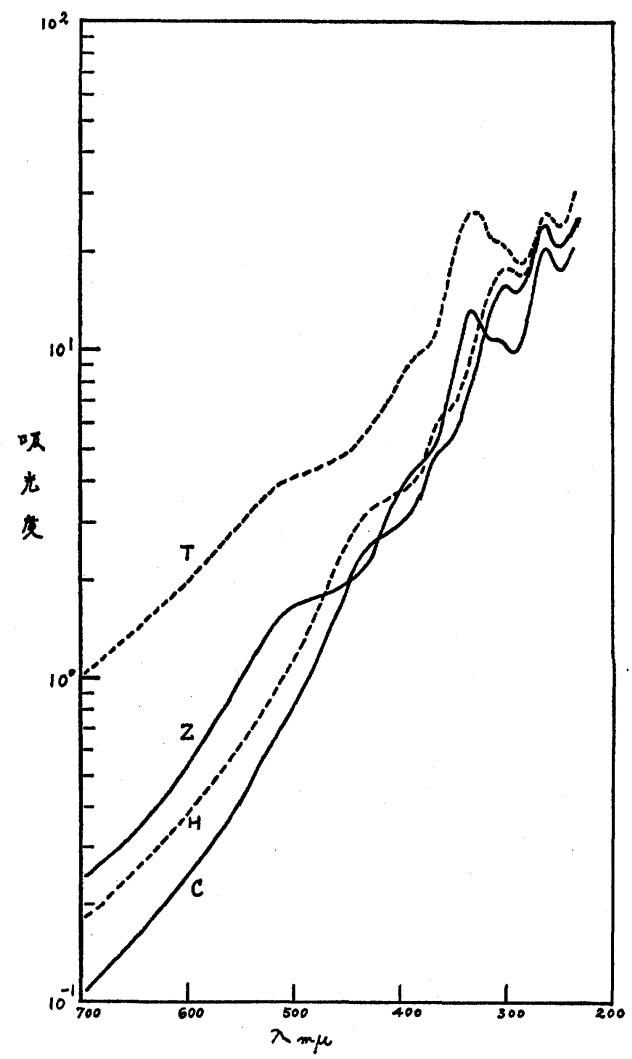

第 1 図ピロガロールの褐変と土壤 (48 時間静置) $\mathrm{C}$ : 対照, $\mathrm{T}$ ：天文台添加, $\mathrm{Z}$ : 善師野添 加, $\mathrm{H}$ : 東山添加, 以下の眓も同様. 


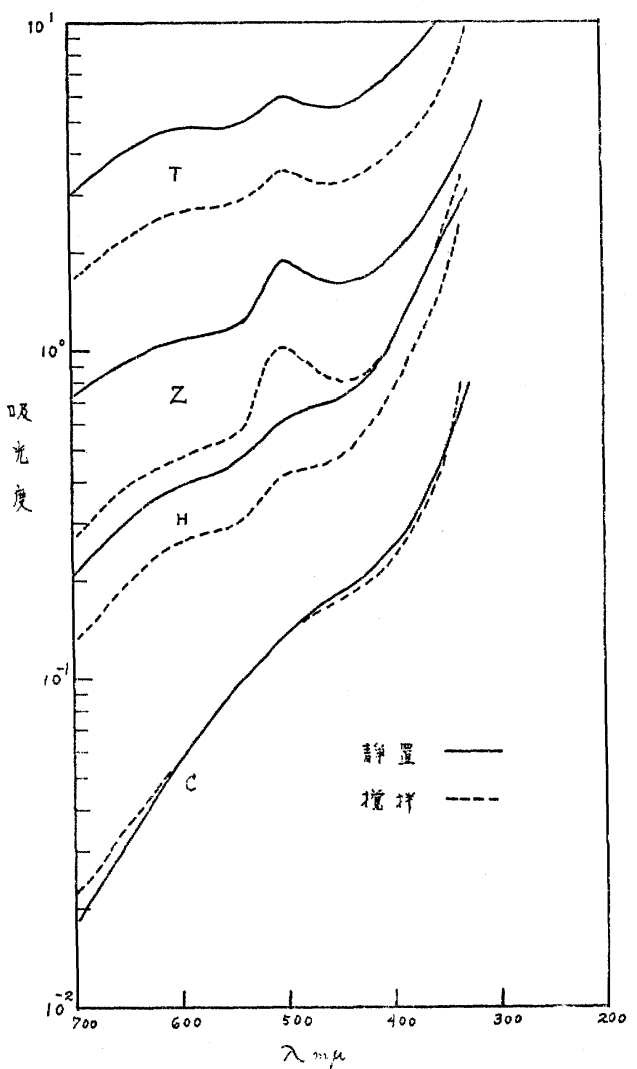

第 2 図 カテコールの褐変と土壤 (48 時間静置または擋汼)

ピロガロール液にアロフェン, アルミナ, Al イオン などが共存すれば, $266 \mathrm{~m} \mu$ 以外の吸収帯は 330,390 ， $500 \mathrm{~m} \mu$ に移動子る.これは Al・プルプロガリン錯化合 物の生成によるものである.

2. カテコールでは, 溶液の色は茶褐色が次第に濃く なるが, 吸光曲線は $350 \mathrm{~m} \mu$ 付近より長波長域に向って 下降して, 明らかな吸収帯は認められない,アルミナ が共存すれば $500 \mathrm{~m} \mu$ に，吸収極大が出現するが，これ は Al イオンとカテコールに由来する末知物質との錯化 合物によるものであろう。 また鉄イオンが共存すれば $575 \mathrm{~m} \mu$ 付近を中心とする幅広い吸收帯が認められ，溶 液は濃い紫色を呈する.なおカテコールは第二鉄イオン と安定なキレートを形成することが知られている.

3. ヒドロキノンの場合にも, カテコールに類似した 吸光曲線がみられ，吸収帯の存在は不明膫である、ただ しカテコールと異なり，Al または鉄との錯化合物は生 成されないようである。

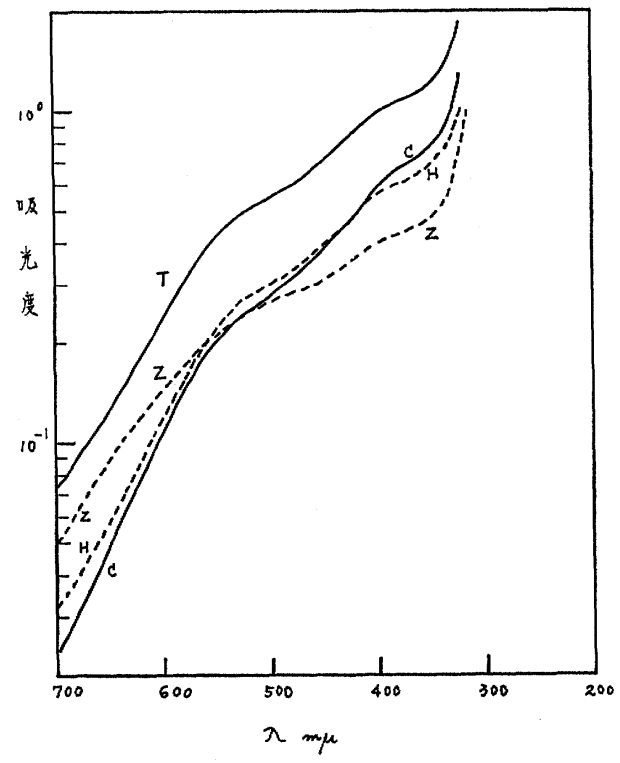

第 3 図ヒドロキノンの褐変と土壤（48 時間静置）

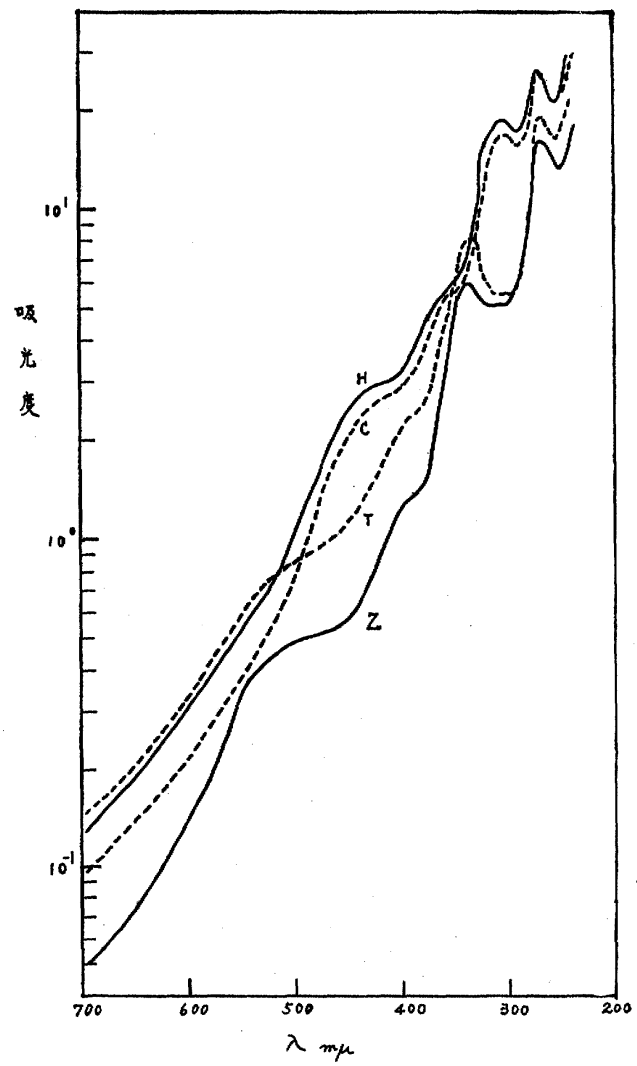

第 4 困 ピロガロールの褐変と土壤（48 時間擋拌） 
第 1 表 土壤の酸性, 粘土鉱物および色

* 新井重光 (未発表) による

** 風乾試料

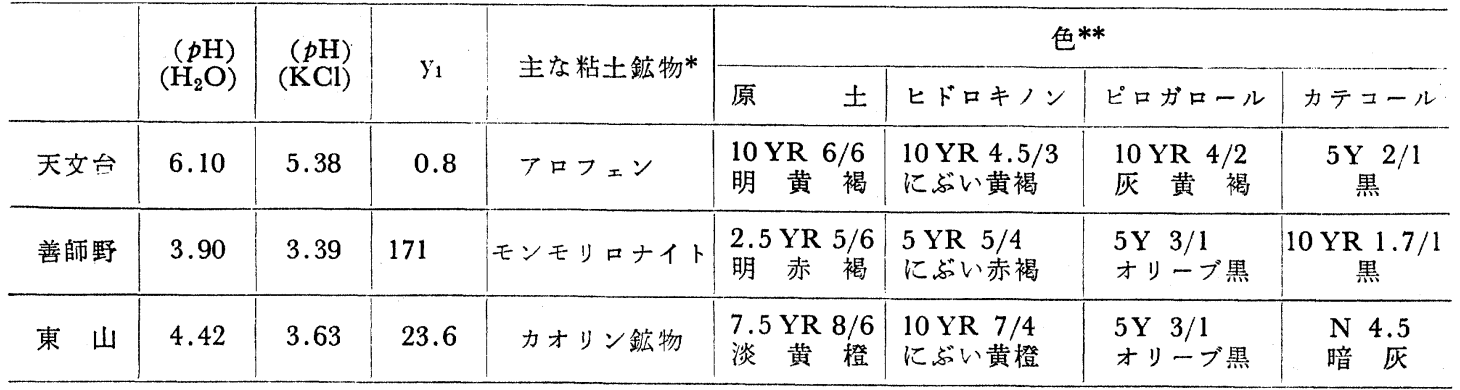

多種類の有機化合物について, 褐変に伴なう吸光曲線 の变化を調ベた著者らの知見（熊田：1961）によれば， 一般に褐变物質の吸光曲線は長波長部から短波長側に向 って上昇する平滑な曲線を示し，明らかな吸収帯をもた ないか，もつとしても肩状できわめてブロードなもの である、なお，吸光曲線の波長軸に対する傾きは，褐変 の進行につれて 小さくなるか, あるいはほとえど変化 しない.

さて, 実験 I の結果から, 以下の点を指摘できよう.

1. 3 種のポリフェノールに共通して，土壤物質の添 加により，ほぼ全波長域. とくに可視部の光吸収の增加 が認められる。 また, 光吸収は概して短波長部から長波 長域にかけて下降するなだらから曲線をとるが，その形 状は，ポリフェノールと土壤の種類によってかなり相異 する・

2. ピロガロール(第 1 図)では，東山土壤添加の試料 の吸光曲線は対照と同様であるが，天交台と善皈野では 吸収帯は赤色移動しており． $\mathrm{Al}$ ・プルプロガリンの生成 が推定される.第 1 表に記載したように, 善師野は $p \mathrm{H}$ が 低く, 置換酸度が著るしく大きいモンモりロナイト質土 壤である. 元来強酸性である本土壤の交換性Alはアロフ

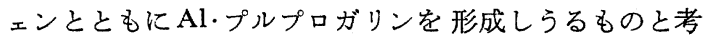
えられる・東山土壤も酸性であるが, 粘土鉱物はカオリン 系であり，その活性 $\mathrm{Al}$ の量は少ないのであろう.なお 48 時間後の溶液の色は, 対照（黄色）と同様であった。

3. カテコール（第 2 図）の場合 $500 \mathrm{~m} \mu$ にみら る鮮明なピークは $\mathrm{Al}$ とカテコールに由来する未知物質 との錯化合物の狱成によると考えられるが，その本体は 目下不明である.このピークより長波長域にみられる幅 広い吸収は $\mathrm{Fe} \cdot$ カテコールキレートの生成によると思 われる、これらの錯化合物の形成は，天文台でもっとも 著るしく, 善師野でも明瞭であったが, 東山ではごく僅
少である.な拉この順に溶液の色は，濃紫色，青紫色， 淡褐色であり, 対照は東山よりもさらにうすい淡褐色で あった。

4.ヒドロキノン（第3 図）の場合, 善師野でやや珙 なる吸光曲線がえられたが，その他の形状はほとえど同 様であった：溶液の色は天文台 (赤褐色), 善師野 (淡黄 褐色), 東山と刘照（淡赤褐色）であった.

5. 以上の溶液の吸光度は時間の経過につれて増大 し, 同時に吸光曲線の形状は一層ブロードになる傾向が あった・

6. 溶液の吸光度に及ぼす攪汼の影響は顕著であり, 対照以外では, 攪捧によって吸光度は著るしく低下した， この様相は第 1 図と第 4 図および第 2 図の静置と攪捧の 吸光曲線を比較すれば明らかである.このことは添加し た土壤物質への褐变物質の吸着が攪挥によって促進され たためと解釈できる. 事実, ピロガロールとカテコール の場合, 土埕はいずれもほとんど黒色に変化した. しか しヒドロキノンでは, 土壤の着色はごく少なく, 第 3 図の 吸光曲線は攪拌によってほとんど影響をうけなかった。

実験 I の条件下でのポリフェノールのみの褐変はきわ めてゆっくり進行し，48 時間後も対照溶液の色はごく うすく着色するにすぎない，しかしこれに土壤物質を添 加すれば，著るしく呈色が認められる．この呈色には， $\mathrm{Al}$ または鉄とピロガロールまたはカテコールおよびこ れらに由来する反応生成物との錯化合物の生成によると ころが大きいのは，上述した諸事実から明らかである. しかしこのような錯化合物の生成の認め難いヒドロキ, ンの場合にも, 土壤物質の添加による可視部光吸収の増 加は明瞭であった.おそらくは錯化合物生成反応と平行 的に，いわゆる褐变反応が進行しており，その程度もま た天文台, 善師野, 東山の順に前者ほど著るしいのであ ろう. 褐変物質による光吸収は上掲の吸光曲線における 
第 2 表 形 態 分 析 $の$ 結 果

$\mathrm{HT}, \mathrm{a}, \mathrm{b}$ はそれぞれ試料 $1 \mathrm{~g}$ 当りの $0.1 \mathrm{NKMnO}_{4}$ 消費量.

RF， $\operatorname{logK}$ および PQについては交献 (Kumada et al 1967) 参照.

\begin{tabular}{|c|c|c|c|c|c|c|c|c|c|c|}
\hline & & \multirow{2}{*}{$\begin{array}{l}\text { 全有機 } \\
\text { 物量 } \\
(\mathrm{HT})\end{array}$} & \multirow{2}{*}{$\begin{array}{c}\text { 抽出割合 } \\
\mathrm{a}+\mathrm{b} / \\
\text { HT }\end{array}$} & \multicolumn{3}{|c|}{ 简 植 酸 部 } & \multicolumn{4}{|c|}{ フル ボ 酸 部 } \\
\hline & & & & a & RF & $\Delta \log \mathrm{K}$ & $\mathrm{b}$ & RF & $\Delta \log \mathrm{K}$ & $P Q$ \\
\hline カテコール & $\begin{array}{l}\text { 天交台 } \\
\text { 善師野 } \\
\text { 菓 }\end{array}$ & $\begin{array}{c}131 \mathrm{~m} l \\
124 \\
47.5\end{array}$ & $\begin{array}{l}33 \% \\
37 \\
36\end{array}$ & $\begin{array}{l}25.0 \mathrm{ml} \\
32.2 \\
7.9\end{array}$ & $\begin{array}{l}367 \\
402 \\
415\end{array}$ & $\begin{array}{l}0.255 \\
0.208 \\
0.164\end{array}$ & $\begin{array}{l}17.5 \mathrm{ml} \\
13.1 \\
9.2\end{array}$ & $\begin{array}{l}150 \\
124 \\
123\end{array}$ & $\begin{array}{l}0.528 \\
0.541 \\
0.573\end{array}$ & $\begin{array}{l}59 \% \\
71 \\
46\end{array}$ \\
\hline ピロガロール & $\begin{array}{l}\text { 天交台 } \\
\text { 善師野 } \\
\text { 東山 }\end{array}$ & $\begin{array}{l}103 \\
104 \\
100\end{array}$ & $\begin{array}{r}100 \\
93 \\
84\end{array}$ & $\begin{array}{l}19.0 \\
26.0 \\
33.0\end{array}$ & $\begin{array}{l}239 \\
232 \\
234\end{array}$ & $\begin{array}{l}0.471 \\
0.480 \\
0.511\end{array}$ & $\begin{array}{l}83.7 \\
70.7 \\
50.6\end{array}$ & $\begin{array}{l}61 \\
90 \\
94\end{array}$ & $\begin{array}{l}0.782 \\
0.674 \\
0.748\end{array}$ & $\begin{array}{l}19 \\
27 \\
39\end{array}$ \\
\hline ヒドロキノン & $\begin{array}{l}\text { 天交台 } \\
\text { 善師野 } \\
\text { 東 山 }\end{array}$ & $\begin{array}{c}89.6 \\
19.4 \\
6.06\end{array}$ & $\begin{array}{l}91 \\
68 \\
86\end{array}$ & $\begin{array}{c}40.9 \\
4.85 \\
1.58\end{array}$ & $\begin{array}{l}172 \\
129 \\
145\end{array}$ & $\begin{array}{l}0.433 \\
0.508 \\
0.473\end{array}$ & $\begin{array}{l}49.3 \\
8.37 \\
3.63\end{array}$ & $\begin{array}{r}33 \\
8 \\
21\end{array}$ & $\begin{array}{l}0.772 \\
0.872 \\
0.859\end{array}$ & $\begin{array}{l}45 \\
37 \\
30\end{array}$ \\
\hline
\end{tabular}

ピーク又は肩状の吸収帯を控除したベースラインとし て，短波長部から長波長側に向ってゆるやかに下降する 曲線であると考えられるからである．ただし，Al また は鉄イオンが褐变反応自体に促進的に機能するか否かに ついては，さらに検討を必要とすることは申すまでもな W.

以上の結果から， $\mathrm{Al}$ (および鉄) とポリフェノールな らびにその関連化合物との錯化合物の生成, 褐变反応, 褐変物質の土壤への吸着はいずれも, 天交台, 善師野, 東山の順に前者ほど著るしいと判断される。

実験 Iでえられたエタノール抽出物溶液の吸光曲線は 第 5 図にあげた.ピロガロール・善師野試料では $480 \mathrm{~m} \mu$ 付近にピークをもつ吸光曲線がえられ，特定の化合物の 生成が推定される.この他の吸光曲線はすべて, 不明確 な吸収帯をもつか，あるいは全く吸収帯を有しない。従 ってここにえられた抽出物の主体は褐変物質であると考 えてよいであろう、なお天文台土壤にピロガロールとカ テコールを添加したものでは, 有色物質は全く抽出され なかった、エタノール抽出物の内容を検討すれば，土壤 の機能を知る手掛かりが与えられる可能性があるが，今 後に残された問題である。

エタノール抽出残椬の色（風乾物）は第 1 表に記載し た.これによれば，ポリフェノールの添加によって，カ テコールは土壤をほとんど黑色化し，ピロガロールも黒 褐色化しており, ヒドロキノンの場合にも, 明度, 彩度 ともに低下していることは明らかであり, 土壤間の相違 は認め難い。

エタール抽出残椬について, 腐植の形態分析を行なっ た結果は，第 2 表のとおりである. ポリフェノールを材 料とする本実験の試料にアルカリによる加熱抽出を適用

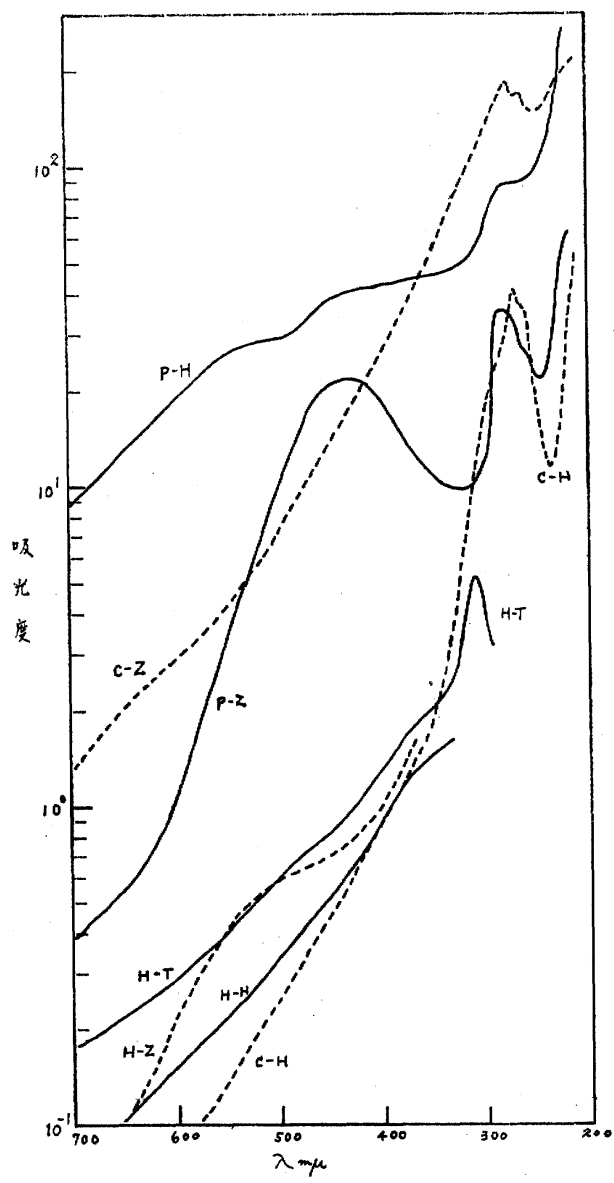

第 5 図エタノール抽出物の吸光曲線 P: ピロガロール, $\mathbf{C : ~ カ テ コ ー ル , ~}$ $\mathrm{H}$ : ヒドロキノン, $\mathrm{Z}$ : 善師野, $\mathrm{H}$ : 東山, $\mathrm{T}$ : 天交台. 


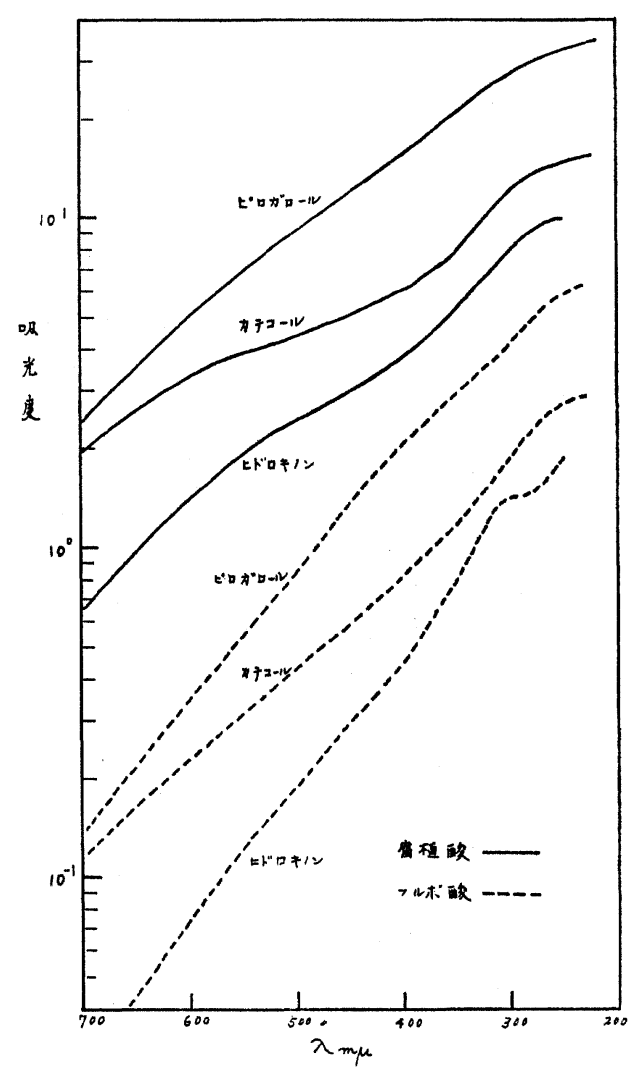

第 6 図フルカリ抽出液の腐植酸部とフルボ酸部の 吸光曲線（天文台土壤，濃度は適宜）

することは，有機物の変質を招来する危険が大きく，問 題であるが，一応この点を無視して第 2 表の結果をなが めることとする.

残留する有機物量は，ピロガロール添加の場合，土壊 聞の相違はなく，著るしく多く，抽出割合も高い. カテ コール添加の場合には，全有機物量は東山のみ少なく， 他の 2 土壤では多いが，アルカリによる抽出量はいずれ も少ない，ヒドロキノンでは，天文台のみ全有機物量は 多く，その他では著るしく少ないが，抽出割合は高い，

しかし，これらの相違を解釈することは，現在のところ 不可能である.

抽出された有機物を腐植酸とフルボ酸に分別し，その 量とともに RF， $\Delta \log \mathrm{K}$ などを算出した結果を概観す れば， RF と $\Delta \log \mathrm{K}$ は材料であるポリフェノールの種 類によって大きく支配され，土壤による相違は明確には 認め難い.なお，カテコール，ピロガロール，ヒドロキ ノンの順に前者ほど， RF 值が大きく $\Delta \log \mathrm{K}$ 值の小さ いものがえられている. 吸光曲線の形状は, 腐植酸, フ
ルボ酸ともに，ポリフェノールの種類によって相違する が，同一ポリフェノールでは土壤間の相違は認められな かったので，天文台土壤の場合のみを第 6 図に例示し た.いずれの曲線も長波長部から短波長側に向って上昇 し，吸収帯は認められない。

つぎに，アルカリ抽出よりも穏和と思われる抽出法を 試みた。まず, $0.1 N$ 酢酸塩緩衝液では, 抽出液はごく わずかに着色するか，またはほとんど無色であった。 $0.1 N$ 弗化ナトリウム $(p H$ 7.25) および $0.1 M$ ピロり ン酸ナトリウム溶液 $(p \mathrm{H} 6.0)$ では著量の褐変物質が 抽出された。 この事実は，裪変物質の吸着には $\mathrm{Al}$ また は鉄酸化物との結合が関与している可能性を示唆するも のである.

第 7 図はピロリン酸ナトリウムによる抽出物の吸光曲

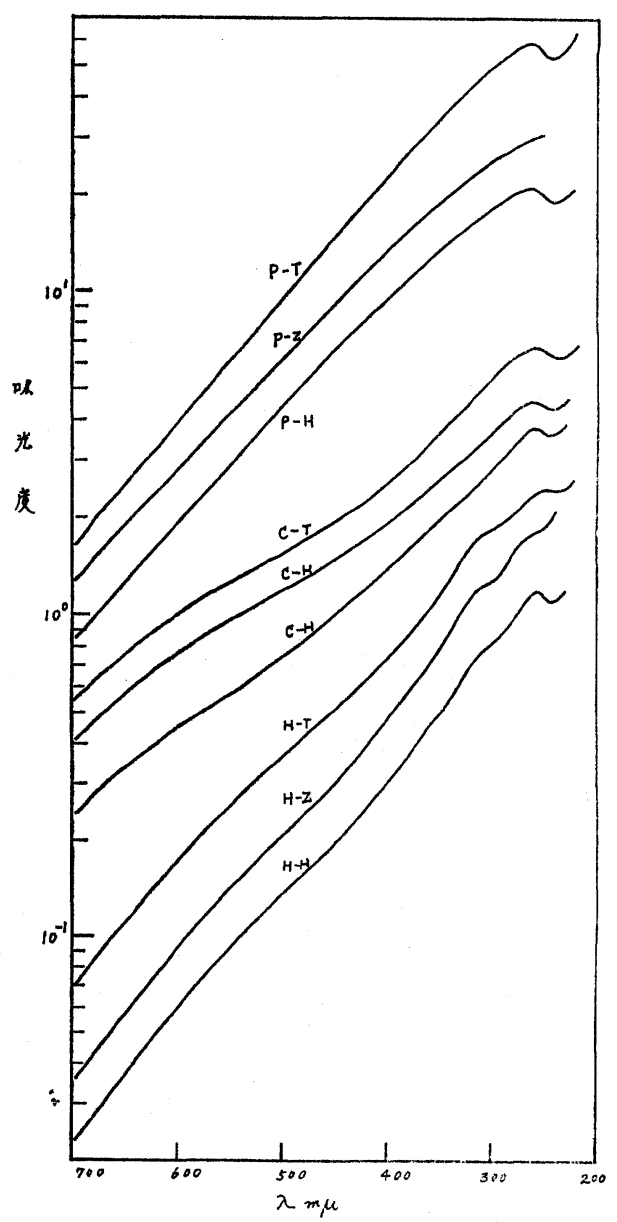

第 7 図ピロリン酸ナトリウム抽出液の吸光曲線 (濃度は適宜).

因中の記号は第 5 図に同じ， 
第 3 表 水酸化ナトリウムとピロリン酸ナトリウムによる抽出液の比較 (濃度 試料 $1 \mathrm{~g}$ : 抽出液 $30 \mathrm{~m} l$ )

\begin{tabular}{|c|c|c|c|c|c|c|c|c|c|c|}
\hline & & \multicolumn{3}{|c|}{ ピロガロール } & \multicolumn{3}{|c|}{ カテコール } & \multicolumn{3}{|c|}{ ヒドロキノン } \\
\hline & & 天交台 & 善師野 & 東 山 & 天文台 & 善師野 & 東 山 & 天交台 & 善師野 & 東 山 \\
\hline $\begin{array}{l}\text { 水酸化ナトリウム } \\
\text { 抽 出 }\end{array}$ & $\mathrm{K} 600$ & 9.60 & 12.3 & 12.5 & 11.6 & 14.6 & 5.08 & 10.1 & 0.96 & 0.34 \\
\hline $\begin{array}{l}\text { ピロリン酸 } \\
\text { ナトリウム抽出 }\end{array}$ & $\begin{array}{l}\mathrm{K} 600 \\
\Delta \log \mathrm{K}\end{array}$ & $\begin{array}{l}11.2 \\
0.753\end{array}$ & $\begin{array}{l}12.2 \\
0.665\end{array}$ & $\begin{array}{c}11.2 \\
0.690\end{array}$ & $\begin{array}{l}14.9 \\
0.406\end{array}$ & $\begin{array}{l}8.33 \\
0.400\end{array}$ & $\begin{array}{l}0.73 \\
0.478\end{array}$ & $\begin{array}{l}6.58 \\
0.647\end{array}$ & $\begin{array}{l}0.50 \\
0.726\end{array}$ & $\begin{array}{l}0.20 \\
0.727\end{array}$ \\
\hline
\end{tabular}

線である・この例では溶液をアルカリ性として測定した が，抽出液をそのまま測定した場合にも大きな相達はみ られなかった・ここに用いた実験条件では甚しい变質は おこらなかったと思われるが，得られた抽出物はいずれ も平滑で吸収帯をもたず，褐变物質が主体をなすものと 考えてよいであろう.

第 3 表は既述のアルカリ抽出液とピロリン酸ナトリウ ム抽出液のアルカリ溶液における K 600 值（波長 600 $\mathrm{m} \mu$ における吸光度) と $\Delta \log \mathrm{K}$ (K $400-\mathrm{K} 600$ の対数 值)を土壤 $1 \mathrm{~g}$ : 溶液 $30 \mathrm{ml}$ に換算して比較したもの である.この表によれば，ピロガロール添加土壤では水 酸化ナトリウムとピロリン酸ナトリウムにより，ほぼ同 量の有色物質が抽出されていること, カテコールでは天 交台の場合ピロリン酸ナトリウムの方が多く, 善師野と 東山では逆であること，ヒドロキノンでは水酸化ナト リウムの 50\% 以上がピロリン酸ナトリウムで抽出され たことがわかる.なおピロリン酸ナトリウム抽出物の $\Delta \log \mathrm{K}$ 值も，ポリフェノールと土壤の 種類により異な っている.

これらの数值の意味については，さらに検討しなけれ ばならないが，全般的に土壤間の相違よりもポリフェノ 一ルの種類による相違の方がより明らかに認められる. 実験 Iにおいてもっとも活性が低かった東山土壤の場合 にも, ピロガロールとカテコールでは著量の有機物が残 留したことからみて，これらのポリフェノールを土壤に 混和して長期間放置すれば，ポリフェノール自体の自動 酸化によって多量の褐変物質が生成され，そのため土壤 物質の効果は打ち消されたのであろうと考えられる.こ れに対して，これら2種のポリフェノールよりも反応性 に乏しいヒドロキノンが土壤中に拉かれた場合には，土 壤物質による褐变促進勃果が明らかに認められたのであ ろう.

このように考えれば，ヒドロキノンはこの種のモデル 物質として最適であると思われる。

ヒドロキノンを添加した天文台土壤では，他の 2 土壤
に比し全有機物量は著るしく多く, また抽出された褐変 物質は RF 值が大きく $\Delta \log \mathrm{K}$ 值の小さい“腐植化度の 高いもの”であった。これらの点は使用した土壤のA層 の腐植酸の相違とかなりよい対応を示しているからであ る.

以上の実験は experimental pedology として, もっと もレベルの低いモデル実験の 1 つにすぎないが，腐植の 生成機棈, それに対する粘土の役割, さらには腐植粘土 複合体の生成機構などを解明する 1 つの方法として, さ らに検討する価值はあるものと考える。

\section{4. 要 約}

アロフェンおよびアルミニウムの役割に着目した腐植 土生成機構に関するモデル実験として, 下記の土壤（C 層）の存在のもとでおこるピロガロール，カテコールお よびヒドロキノンの褐变反応を分光光度法によって調べ た。

天文台：腐植質火山兏土, 主な粘土鉱物, アロフェ ン, 善師野: 強酸性赤黄色土, モンモリロナイト, 東 山: 酸性赤黄色土, カオリン鉱物,

天交台および善師野土壤の存在のもとでは, アルミニ ウムとプルプロガリンおよびカテコールに由来する未知 物質ならびに鉄とカテコールからなる錯化合物の生成が 認められた. これらの錯化合物および褐変物質の生成と それらの土壤への吸着は, 天文台, 善師野, 東山の順に 前者ほど大きいことが推論された. 用いたポリフェノー ルのうちでは, ヒドロキノンが最もよいモデル物質であ ると考えられる.

謝 辞 本研究の研究費の一部は文部省料学研究費に よった. 本研究の実施にあたり, 種々御教示いただいた 松井健博士, 黑部隆教授に厚く御礼申し上げる.

\section{引用 交 献}

Dubach, P. and Merta, N. C. (1963) The chemistry of soil humic substances. 26, 293-300. 
熊田恭一（1961）腐植化に関する一考察. 日土肥誌, 32, 466-474.

Kumada, K. Sato, O. Ohsumi, Y. and Ohta, S. (1967) Humus composition of mountain soils in Central Japan with special reference to the distribution of $P$ type humic acid. Soil Sci. Plant Nutr. 13,
$151-158$.

Kumada, K. and Kato, H. (1970) Browning of pyrogallol as affected by clay minerals. I. Soil Sci. Plant Nutr. 16, 195-200.

Scheffer, F. und Ulrich, B. (1960) Humus u. Humusdüngung. 101 s., Ferdinand Enke Verlag. 